\title{
Historical review of clinical vaccine studies at Oswaldo Cruz Institute and Oswaldo Cruz Foundation - technological development issues
}

\author{
Reinaldo de Menezes Martins/ ${ }^{+}$, Cristina de Albuquerque Possas, Akira Homma \\ Conselho Político e Estratégico, Bio-Manguinhos-Fiocruz, Rio de Janeiro, RJ, Brasil
}

\begin{abstract}
This paper presents, from the perspective of technological development and production, the results of an investigation examining 61 clinical studies with vaccines conducted in Brazil between 1938-2013, with the participation of the Oswaldo Cruz Institute (IOC) and the Oswaldo Cruz Foundation (Fiocruz). These studies have been identified and reviewed according to criteria, such as the kind of vaccine (viral, bacterial, parasitic), their rationale, design and methodological strategies. The results indicate that IOC and Fiocruz have accumulated along this time significant knowledge and experience for the performance of studies in all clinical phases and are prepared for the development of new vaccines products and processes. We recommend national policy strategies to overcome existing regulatory and financing constraints.
\end{abstract}

Key words: clinical studies - vaccines - technological development - innovation - regulatory barriers

Clinical studies are crucial for the development and registration of new products and constitute today a structured process, mandated by strict legislation involving a growing number of participants, in a stepwise strategy.

The Oswaldo Cruz Institute (IOC) and the other technical units which constitute the Oswaldo Cruz Foundation (Fiocruz) are recognised as very important institutions for basic science and biological and technological research on tropical diseases in Brazil. These institutions have a long tradition of clinical studies which have proven to be vitally connected to the prevention of infectious diseases of public health importance for Brazil and other countries. In this paper, we review and analyse these studies, occurring over a period exceeding seven decades, from the perspective of technological development (TD). The understanding, in a historical sense, of the evolutionary stages of these clinical studies will hopefully provide a better understanding of the processes that were involved and may help policy and decision-makers to conceive of new alternatives and create possibilities for the design of new studies in the future.

\section{MATERIALS AND METHODS}

For the selection of the clinical studies we adopted the following criteria for inclusion: (i) studies conducted in human beings; (ii) prospective; (iii) vaccination as the basic intervention; (iv) longitudinal and individual follow-up of participants; (v) published in scientific medical journals; (vi) conceived and conducted according to ethical and legal criteria for clinical research in human

\footnotetext{
doi: 10.1590/0074-02760140346

+ Corresponding author: rmenezes@bio.fiocruz.br

Received 22 September 2014

Accepted 5 December 2014
}

beings, with tolerance to the absence of formal ethical and regulatory evaluations regarding the older studies; (vii) conducted with participation of at least one unit or professional of Fiocruz/IOC.

These restrictive criteria, besides being conceptually acceptable, met the requirement to limit the scope of the research within an acceptable range. Studies which did not meet these criteria were excluded. These included retrospective studies, clinical-epidemiological studies, seroepidemiological studies, pharmacovigilance studies and observational studies. Although the latter did not fit into the classical model of clinical studies, some of them could be classified as clinical studies, in a broader sense definition.

For studies conducted at the origin of IOC, which are outstanding and part of its history, these criteria were not strictly applied, which is justifiable, considering that the legislation on clinical studies came later. However, if they are not formally perfect, they have been conducted ethically, with the best science and methodology available at the time.

The search for papers was done by databases, including PubMed, from the National Center for Biotechnology Information, National Institutes of Health, United States of America, and LILACS, the Latin-American database from BIREME-Regional Library of Medicine, from Pan American Health Organization (PAHO)/World Health Organization (WHO). However, most papers were found through personal archives, consultations with colleagues, some reference books on the history of vaccines (Benchimol 2001, Artenstein 2010, Plotkin 2011) and other means, in a process with considerable degree of serendipity in chance encounters.

To recover original papers, we used, besides PubMed and LILACS, the SciELO database, Capes Periodicals Gateway and the libraries of the National School of Public Health, Bio-Manguinhos/Fiocruz and Mourisco Castle. Photocopies were also obtained from the Hinari Programme, from WHO and Oxford Journals.

We use terms "clinical trial" and "clinical study" interchangeably. 


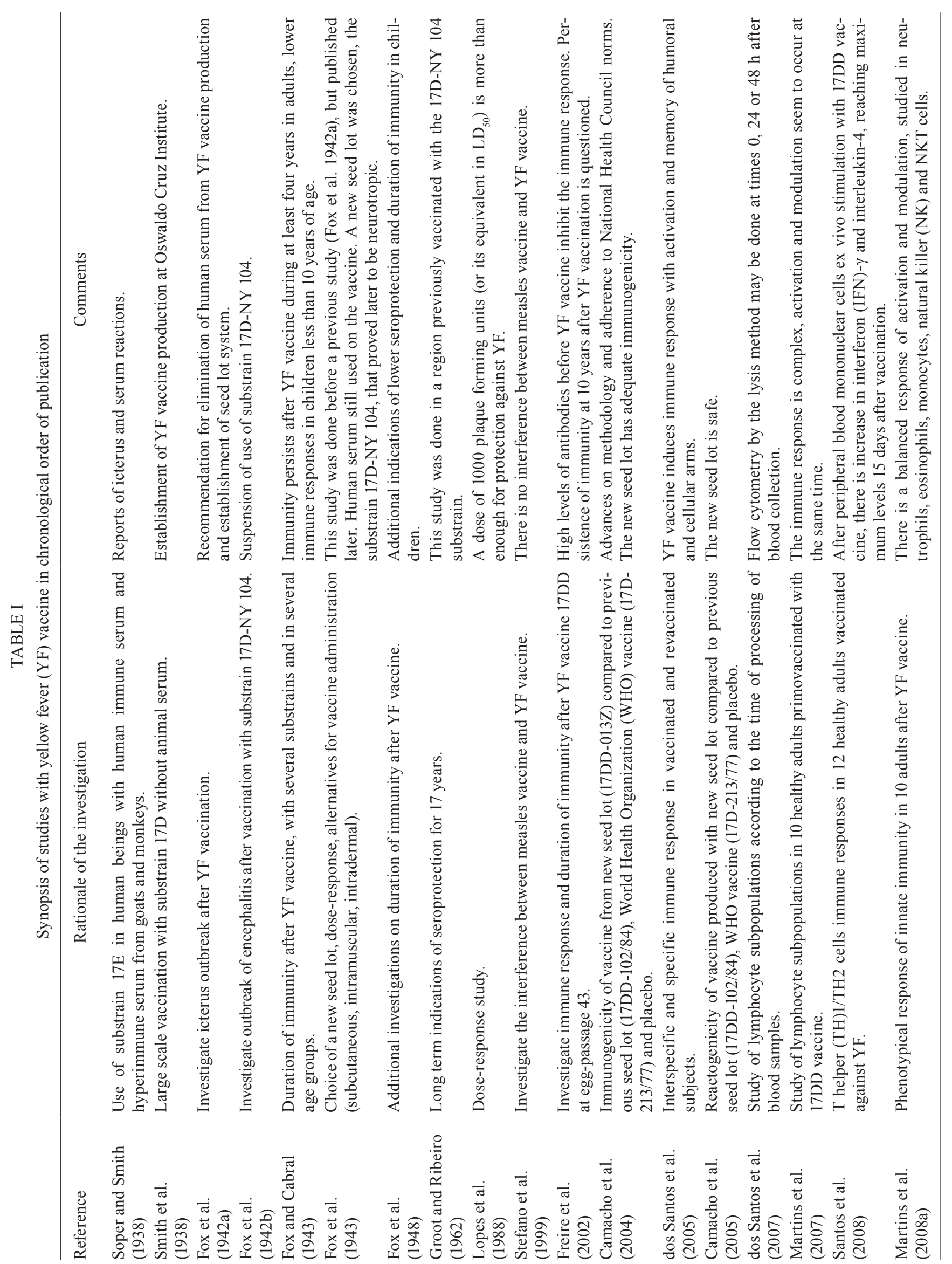




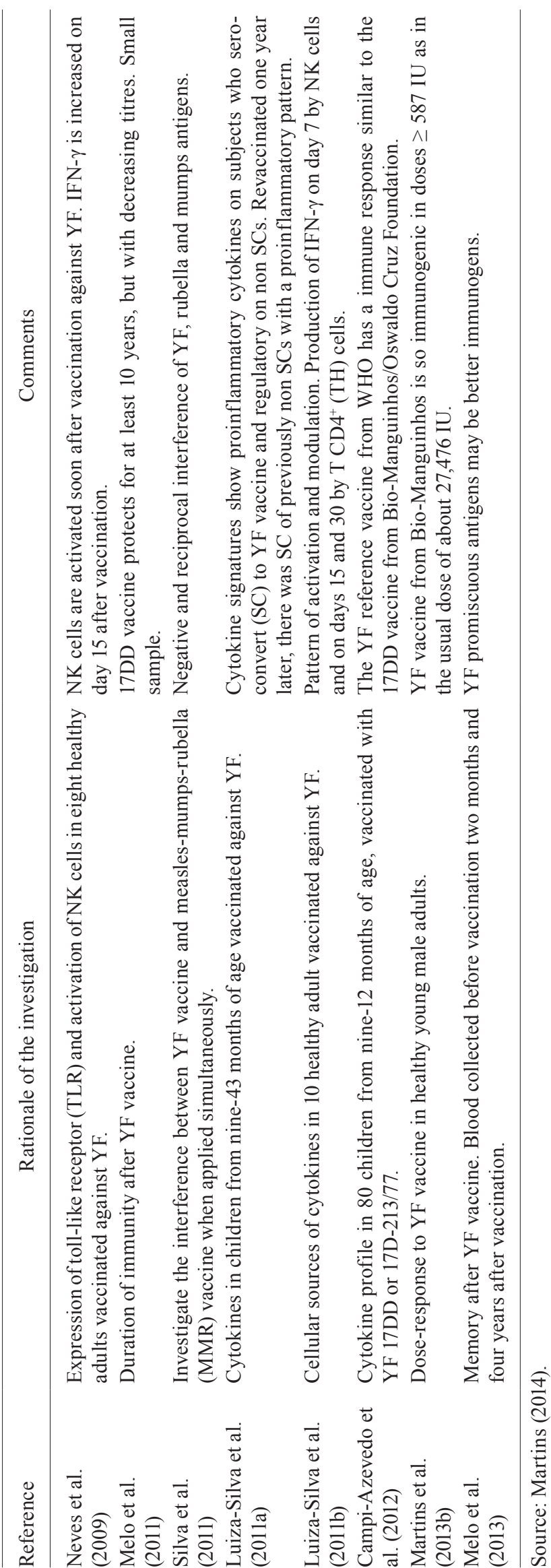

The period of study extended up to the year 2013 (Martins 2014).

\section{RESULTS}

Tables IV show, for each study, its rationale and its basic findings. Table $\mathrm{V}$ shows the number of clinical studies by kind of vaccine (viral, bacterial or parasitic) and its utilisation [commercial or by the National Immunisations Program (NIP)].

\section{DISCUSSION}

The clinical studies with vaccines under the scope of IOC and Fiocruz, besides their relevance to the public health of Brazil and many other developing countries, have contributed to the institutional TD.

These technical advances built institutional knowledge and skills in vaccine thermostability, new freezedrying formulation, use of certified inputs, improvement of quality control methodologies and the skills to incorporate new products through technology transfers, which resulted in scientific breakthroughs and have been landmarks of Fiocruz history.

Examples of tech transfer include the yellow fever (YF) vaccine (Rockefeller Institute), the polysaccharidic AC meningococcal vaccine (Institut Mérieux), the poliomyelitis and measles vaccines (BIKEN Institute), the Haemophilus influenzae Type b (Hib) vaccine, measles/ mumps/rubella (MMR) and rotavirus vaccines [GlaxoSmithKline (GSK)] and shortly the measles/mumps/rubella/varicella (MMRV) vaccine (also with GSK). Besides leading to the introduction of new vaccines into the NIP, in a relatively short time, technology transfers of these vaccines have made possible the creation, expansion and improvement of new platforms, production and laboratories and the creation of a qualified workforce that is now a most valuable asset of Fiocruz. The positive consequences of these innovative processes have been outstanding and should not be minimised. Moreover, transfer of technologies has been feasible because of the intrinsic capacity of the institution for absorbing, in a relatively short span of time, the newly involved technologies.

The clinical studies of measles vaccines were conducted to evaluate the successful technology transfer and implement the regular use of a vaccine to counteract one of the main causes of child mortality in Brazil (Puffer \& Serrano 1973). The technology of production of this vaccine was obtained thanks to the Brazil-Japan Cooperation Agreement, which involved the participation of BIKEN Laboratory from Osaka University, with Japan International Cooperation Agency and Funding Authority for Studies and Projects as intermediaries. This agreement made possible the development of new projects, which included: (i) an improvement and adaptation of laboratories for the production of viral antigens and formulation, filling and lyophilisation in industrial scale, (ii) the provision of industrial equipment, (iii) "on the bench" training in Japan and the beginning of production operations and (iv) the clinical studies in the states of Pernambuco and Pará. This project gave Bio-Manguinhos the opportunity to build the infrastructure for industrial production to meet today's good manufactur- 


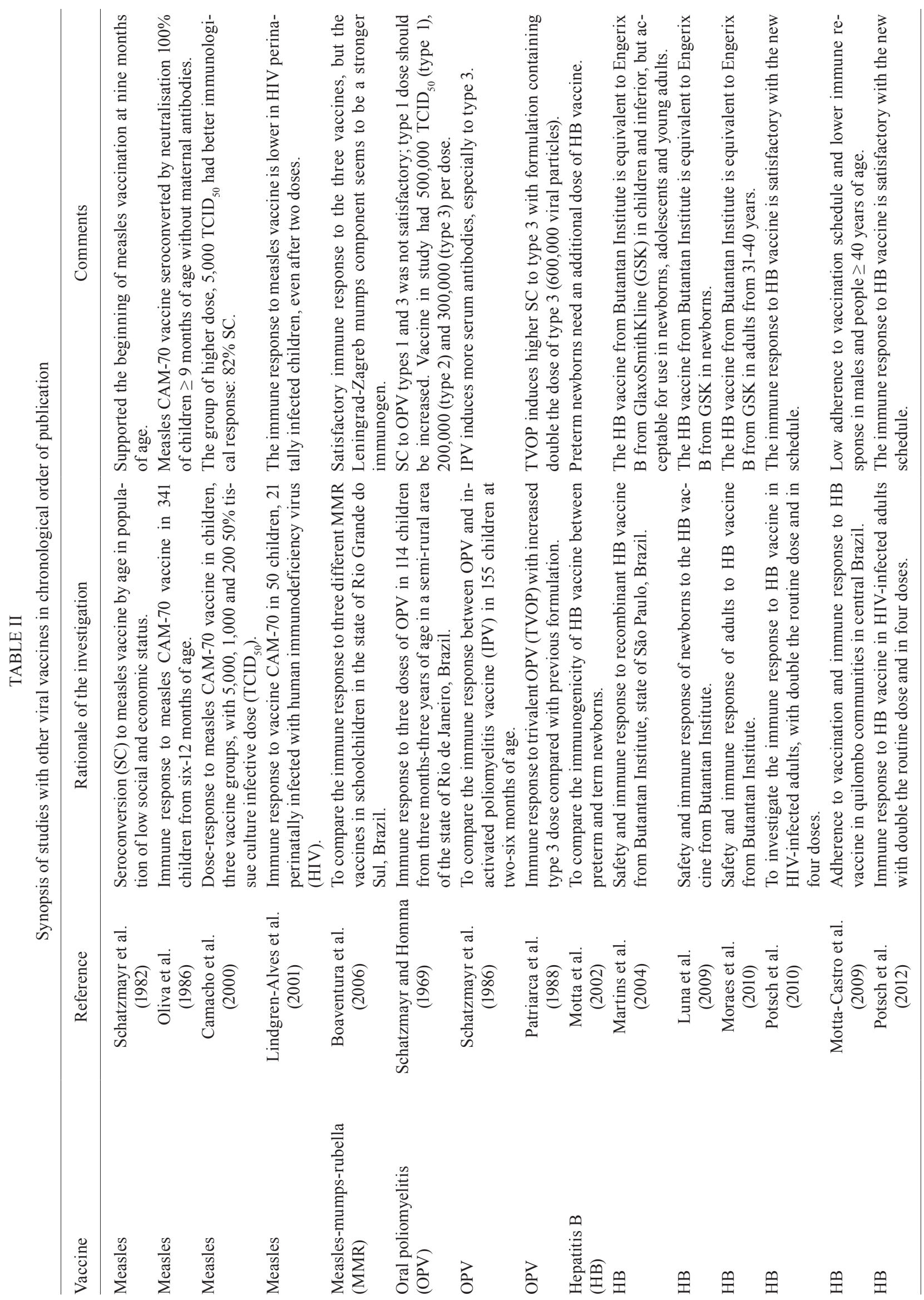




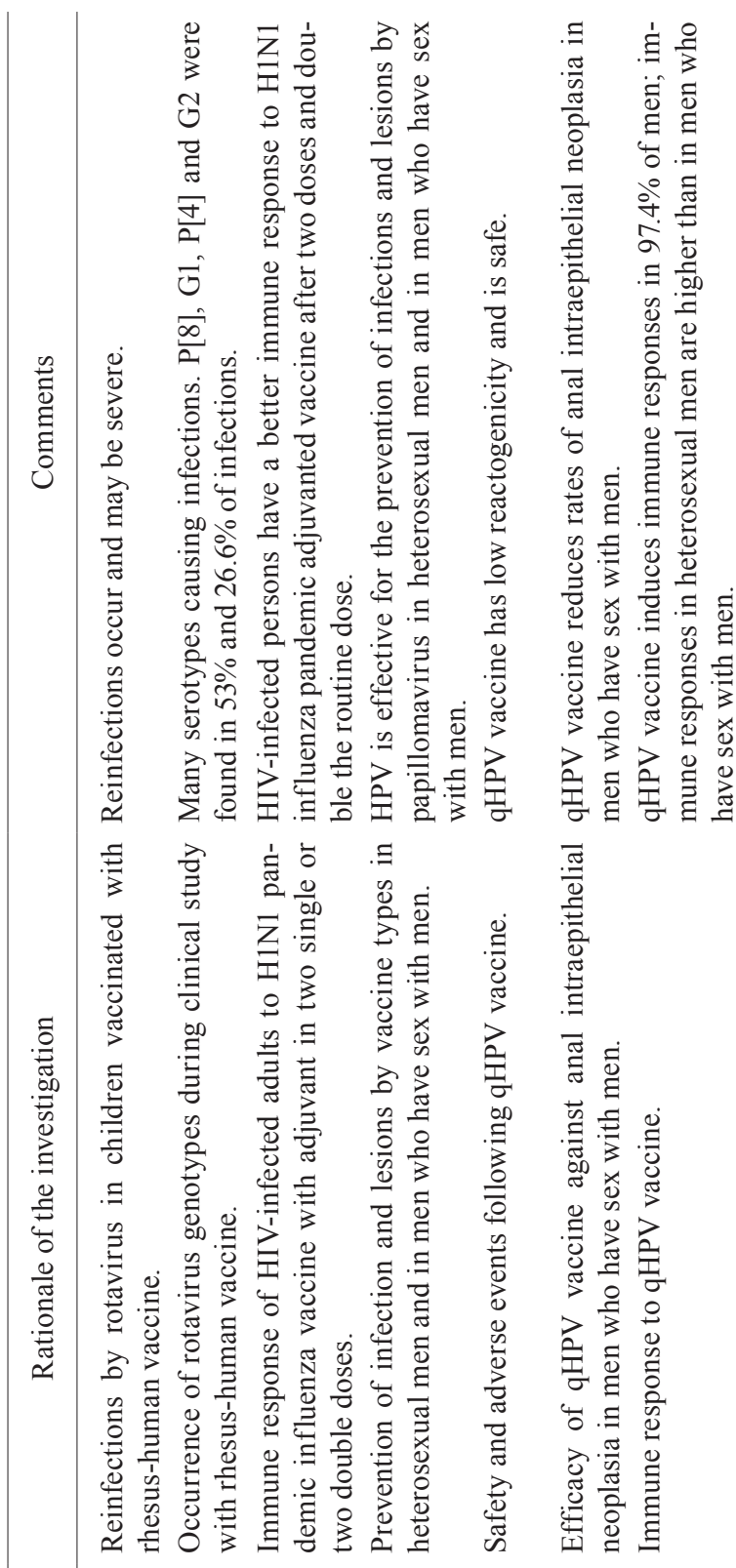

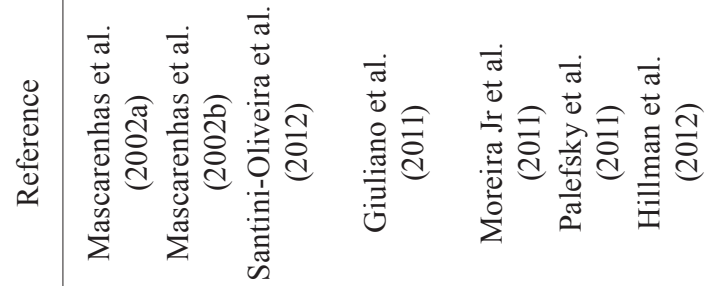

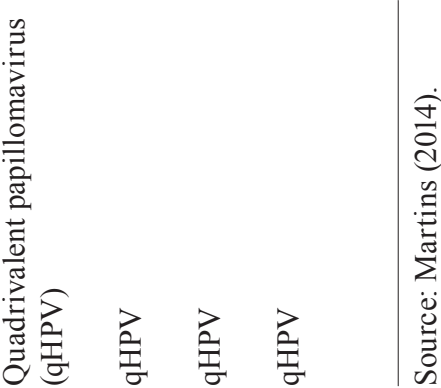

ing practices requirements. This required new organisational structures including independent departments for production, quality control and management which, in a step by step process, resulted in the provision of good quality vaccines for the NIP. Because of this successful activity, Bio-Manguinhos is now prepared to provide the MMR and MMRV vaccines to the NIP.

The clinical studies with poliomyelitis vaccines and many additional seroepidemiological studies resulted in changes and improvements in vaccine composition and eventually resulted in the elimination of this disease in Brazil and many other Latin American countries.

As with the measles vaccine, the oral polio vaccine (OPV) technology was obtained under the umbrella of the Brazil-Japan Cooperation Agreement. The technology transfer for this vaccine came through the Japanese Poliomyelitis Research Institute. These actions included redesigns and upgrades of facilities, provision of equipment, "on the bench" training within production laboratories, quality control and neurovirulence testing in nonhuman primates. The creation of this highly qualified group in 1982 allowed Bio-Manguinhos to take the responsibility for the quality control testing of the OPV vaccine used in the national routine immunisation program or in mass campaigns. Later, this responsibility was transferred to the National Institute for Quality Control. Another great contribution from Bio-Manguinhos was the formulation improvements of OPV vaccine, including a doubling of the dose of type $3 \mathrm{OPV}$, required to control poliomyelitis outbreaks in Northeast Brazil. This formulation change was accomplished in just two weeks after the decision was made. The highly satisfactory results led the PAHO to extend this recommendation to all Latin American countries and, afterwards, WHO recommended the use of the same formulation for all countries.

The clinical studies with diphtheria, tetanus and pertussis/Hib vaccine drove the technology transfer for the Hib portion of the vaccine. This resulted in the introduction of this vaccine into the routine vaccination schedule, which, in a very short time, drastically reduced the incidence of Hib meningitis.

Table $\mathrm{V}$ shows that the clinical studies with viral and bacterial vaccines led to the licensing of these essential vaccines. Almost half these studies were conducted with YF vaccine - a demonstration of the importance of this vaccine for Brazil and the world and the need to improve it, in order to reduce its serious adverse events.

In contrast to the other clinical studies, the ones for parasitic diseases have not led to the licensure of any vaccine. Due to genetic variation of parasites, the epitope multiplicity and the complexity of anti-infectious mechanisms that are very different from virus and bacteria, it has been a big challenge to develop vaccines for parasitic diseases. Here, there is a need for new and innovative approaches. For malaria, there have been attempts to block transmission from the mosquito using vaccines targeting the sexual stages of Plasmodium falciparum (Biswas et al. 2013). In the case of leishmaniasis, there may be a combination of strategies, for example, antigens in nanoparticles (Santos et al. 2013) or a combination of treatment and immunotherapy (Machado-Pinto et al. 2002, 


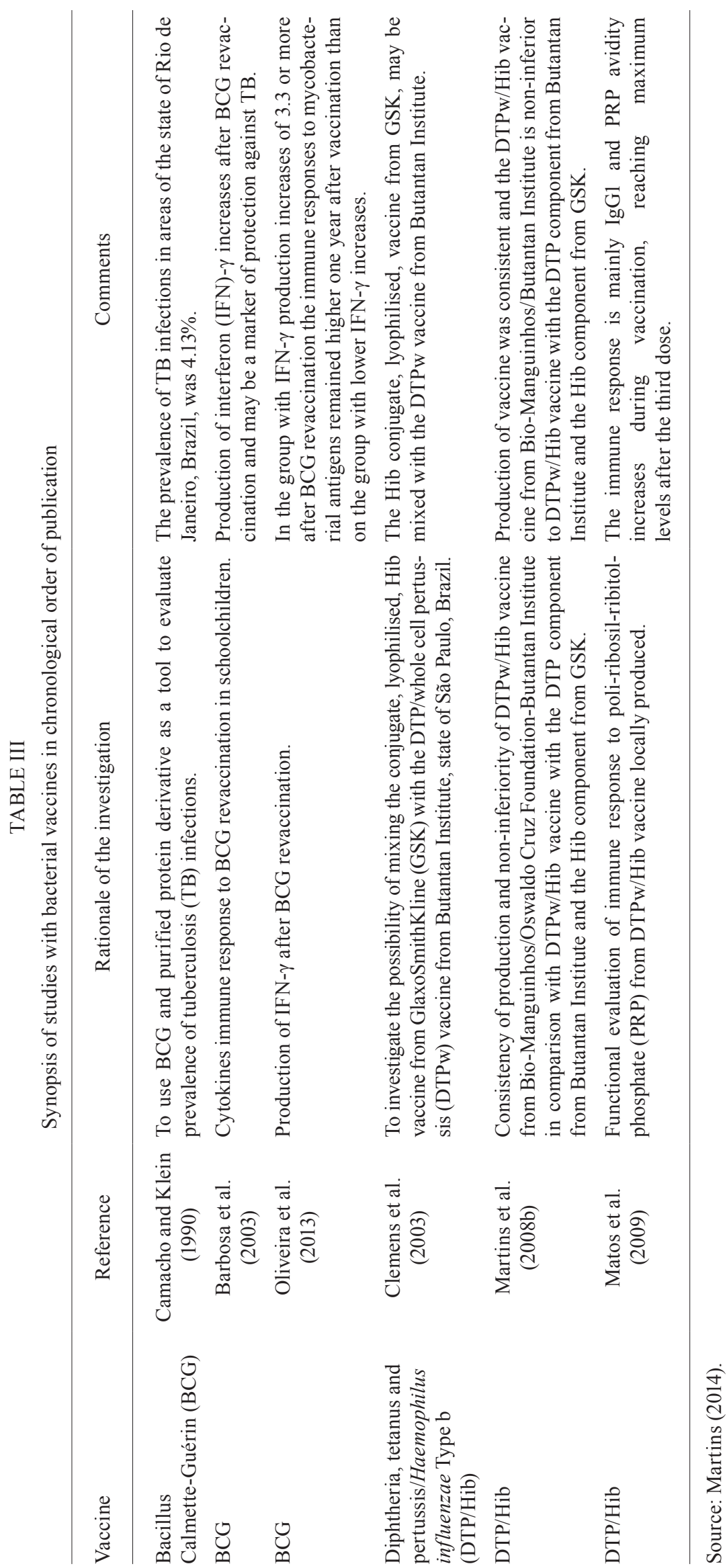




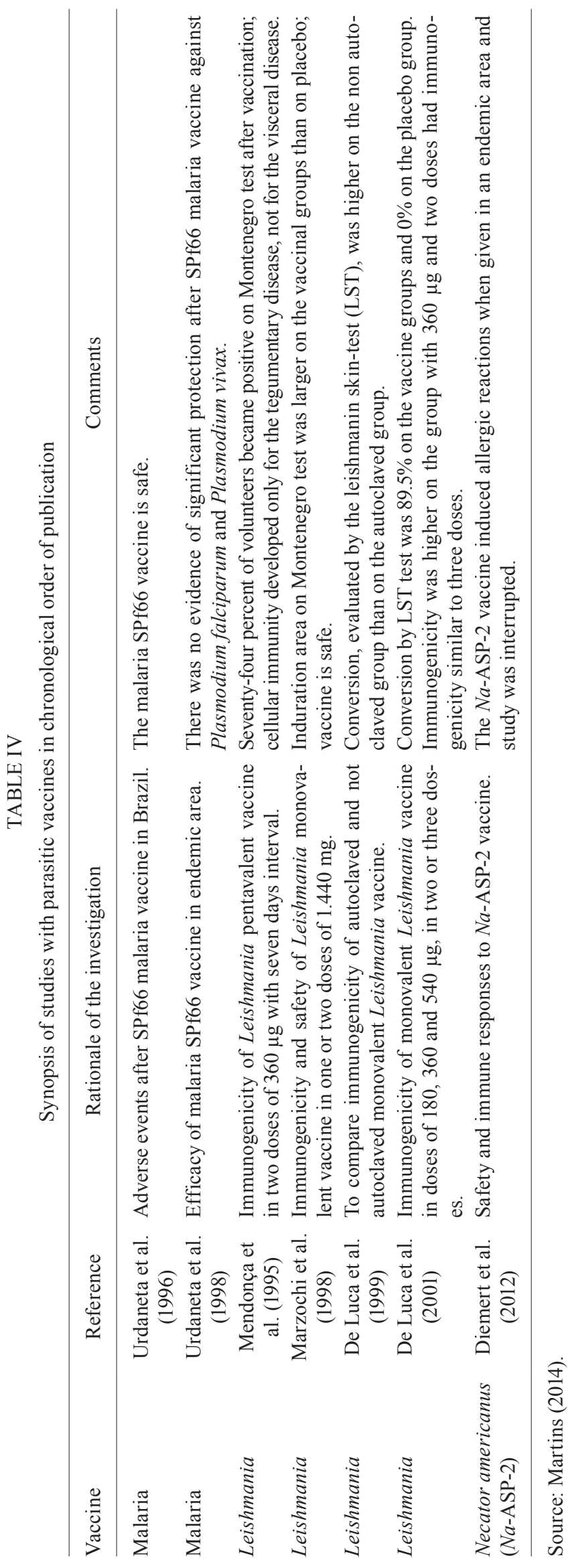

Nascimento et al. 2010). Perhaps the traditional approach for highly effective preventive vaccines will have to be modified to include more modest but even so important objectives, such as disease attenuation or disease blocking transmission strategies.

The difficulties for the development of vaccines for some genetically unstable viruses, such as human immunodeficiency virus and hepatitis $C$, underscore the need to explore new technologies. These would include the presentation of antigens in virosomes and nanoparticles, chimeric vaccines, new adjuvants and new ways for delivering vaccines, such as in patches or microneedles. Other vaccines need improvement, such as for tuberculosis (TB), which needs better protection, and for pertussis and $\mathrm{YF}$, which need improved safety.

Although some of the achievements have been remarkable, we should recognise that innovations at IOC and Fiocruz have been incremental and did not change paradigms (Kuhn 1970). The innovation which results in technological leaps is a process that begins many years before. It involves many groups working in cooperation on many different fields - microbiology, immunology, biochemistry, genetics. It requires the engagement of a critical mass of technological and human resources, a long term financial support and strong coordination and management.

The results presented here indicate that, over the last several years, there have been considerable quantitative and qualitative advances in the development of clinical studies under the scope of IOC and Fiocruz. These demonstrate that clinical studies no longer constitute a bottleneck for innovation, in terms of local capacity. However, regulatory and financial constraints still remain. There are also regulatory and operational issues that need to be addressed, in order to streamline processes without loss of safety and quality. Slow decision-making and excessive centralisation of regulatory and ethical processes may, in fact, decrease the quality of studies and may result in loss of opportunities in a competitive world.

It should be noted that, although not reviewed here, several clinical studies with meningococcal vaccines have been conducted at Bio-Manguinhos/Fiocruz, of which three have been Phase I studies and published in congress annals (Martins et al. 2009a, b, 2010).

Although several new innovative vaccines are in development, their complexity is increasing and will certainly require creativity and scientific and technological capacity to achieve a final product.

It should also be stressed that if we have been weak in technological innovation so far in Brazil, we have been innovators on the ethical concept that vaccines are a right of citizenship and that all people should have free access to them, as to basic sanitary services and education. The vaccine schedule of the Ministry of Health has significantly expanded and now includes all vaccines used by developed countries (Martins et al. 2013a). Moreover, there is a clear perception that vaccines have an excellent cost/benefit relationship and that they contribute to economic development (Bloom et al. 2005).

The contribution of vaccines for the improvement of health conditions of the Brazilian population is evident and outstanding. The infectious diseases targeted by 
TABLE V

Number of clinical studies by type of vaccine

\begin{tabular}{lcc}
\hline Viral vaccines & $\begin{array}{c}\text { Studies } \\
\text { (n) }\end{array}$ & $\begin{array}{c}\text { Licensed } \\
\text { for use }\end{array}$ \\
\hline Yellow fever & 26 & All \\
Hepatitis B & 7 & \\
Quadrivalent papillomavirus & 4 & \\
Oral poliomyelitis & 3 & \\
Measles & 4 & \\
Measles/mumps/rubella & 1 \\
Rotavirus & 2 \\
Influenza & 1 \\
\hline Total & 48
\end{tabular}

\begin{tabular}{|c|c|c|}
\hline Bacterial vaccines & & \\
\hline Bacillus Calmette-Guérin & 3 & All \\
\hline $\begin{array}{l}\text { Diphtheria, tetanus } \\
\text { and pertussis/Haemophilus } \\
\text { influenzae Type b (tetravalent) }\end{array}$ & 3 & \\
\hline Total & 6 & \\
\hline Parasitic vaccines & & \\
\hline Leishmania & 4 & None \\
\hline Malaria & 2 & \\
\hline Necator americanus & 1 & \\
\hline Total & 7 & \\
\hline All clinical studies & 61 & $\begin{array}{c}54 / 61 \\
(88.5 \%)\end{array}$ \\
\hline
\end{tabular}

Source: Martins (2014).

vaccination (except TB) are under control. The Brazilian producers of vaccines made these conquests possible and the clinical studies with vaccines have been an essential part of this process.

The review of clinical studies under the scope of IOC and Fiocruz within the period of this study indicates the strength and potential of IOC and Fiocruz to conduct all phases of clinical studies with vaccines. However, the innovation component is still weak and should be strengthened. To achieve this objective as well as to accelerate the TD of new and innovative vaccines, we suggest: (i) the urgent development of a new legal and institutional framework for Bio-Manguinhos/Fiocruz, allowing flexibility and capacity to produce and to operate in the market. It is necessary to conciliate social commitment with speeding up of processes and entrepreneurial capacity, which are essential to industrial activity and technological competitiveness; (ii) to stimulate intra and inter institutional partnerships and the exchange of personnel, nationally and internationally; (iii) to stimulate group and personal cooperation through meetings and common projects; (iv) to promote public-private partnerships, leading to technology transfers, to search for common development of new products and processes; (v) to stimulate innovation and creativity; (vi) to attract new talent, creating an inspiring and receptive atmosphere and environment to innovation and creativity; (vii) to search for expertise, wherever it may reside, to solve the technological and organisational problems of Bio-Manguinhos/ Fiocruz; (viii) to increase the governmental financing for clinical studies and to stimulate the non-governmental financing; (ix) to stimulate excellence, at all levels.

\section{ACKNOWLEDGEMENTS}

To José Rodrigues Coura, Martha Cecilia Suarez-Mutiz, Luiz Antonio Bastos Camacho, Jaime Larry Benchimol, Gabriel Oselka and Marilda Siqueira, for their valuable suggestions, and to the Bio-Manguinhos Clinical Advisory Unit and Oswaldo Cruz Home/Fiocruz.

\section{REFERENCES}

Artenstein AW 2010. Vaccines, a biography, Springer, New York, $401 \mathrm{pp}$.

Barbosa T, Arruda S, Fernandes BD, Carvalho LP, Cardoso S, Cunha S, Barreto ML, Pereira SM, Rodrigues LC, Barral-Netto M 2003. BCG (Bacille of Calmette-Guérin) revaccination leads to improved in vitro IFN- $\gamma$ response to mycobacterial antigen independent of tuberculin sensitization in Brazilian school-age children. Vaccine 21: 2152-2160.

Benchimol JL 2001. Febre amarela - a doença e a vacina, uma história inacabada, Editora Fiocruz, Rio de Janeiro, 470 pp.

Biswas S, Li Y, Miura K, Zakutansky SE, Long CA, Sinden RE, Draper SJ, Hill F 2013. Enhancing antibody immunogenicity of transmission-blocking malaria vaccines. Am J Trop Med Hyg 89: 351.

Bloom DE, Canning D, Weston M 2005. The value of vaccination. World Economics 6: 15-39.

Boaventura AS, Stralioto SM, Siqueira MM, Ranieri TS, Bercini M, Schermann MT, Wagner MB, Silveira TR 2006. Prevalence of antibodies against measles, mumps and rubella before and after vaccination of school-age children with three different triple combined viral vaccines, Rio Grande do Sul, Brazil. Rev Panam Salud Publica 20: 299-306.

Camacho LAB, Aguiar SG, Nascimento JP, Freire MS, Leal MLF, Iguchi T, Lozana JA, Farias RHG, Grupo Colaborativo para o Estudo das Vacinas de Febre Amarela 2005. Reactogenicity of yellow fever vaccines in a randomized, placebo-controlled trial. Rev Saude Publica 39: 413-420.

Camacho LAB, Freire MS, Leal MLF, Aguiar SG, Nascimento JP, Iguchi T, Lozana JA, Farias RHG, Grupo Colaborativo para o Estudo das Vacinas de Febre Amarela 2004. Immunogenicity of WHO-17D and Brazilian 17DD yellow fever vaccines: a randomized trial. Rev Saude Publica 38: 671-678.

Camacho LAB, Freire MS, Yamamura AMY, Leal ML, Mann G 2000. Estudo de soroconversão com formulações da vacina BIKEN CAM-70 contra sarampo. Rev Saude Publica 34: 358-366.

Camacho LAB, Klein CH 1990. Risco de infecção tuberculosa entre escolares com alta cobertura pelo BCG. Bol Oficina Sanit Panam 108: 100-112.

Campi-Azevedo AC, Araujo-Porto LP, Luiza-Silva M, Batista MA, Martins MA, Sathler-AR, Silveira-Lemos D, Camacho LAB, Martins RM, Maia MLS, Farias RHG, Freire MS, Galler R, Homma A, Ribeiro JGL, Lemos JAC, Auxiliadora-Martins M, Caldas IR, ElóiSantos SM, Teixeira-Carvalho A, Martins-Filho O 2012. 17DD and 
17D-213/77 yellow fever substrains trigger a balanced cytokine profile in primary vaccinated children. PLOS ONE 7: 1-11.

Clemens SA, Azevedo T, Homma A 2003. Feasibility study of the immunogenicity and safety of a novel DTPw/Hib (PRP-T) Brazilian combination compared to a licensed vaccine in healthy children at 2, 4 and 6 months of age. Rev Soc Bras Med Trop 36: 321-330.

De Luca PM, Mayrink W, Alves CR, Coutinho SG, Oliveira MP, Bertho AL, Toledo VP, Costa CA, Genaro O, Mendonça CF 1999. Evaluation of the stability and immunogenicity of autoclaved and nonautoclaved preparations of a vaccine against American tegumentary leishmaniasis. Vaccine 17: 1179-1185.

De Luca PM, Mayrink W, Pinto JA, Coutinho SG, Santiago MA, Toledo VP, Costa CA, Genaro O, Reis AB, Mendonça SCF 2001. A randomized double-blind placebo-controlled trial to evaluate the immunogenicity of a candidate vaccine against American tegumentary leishmaniasis. Acta Trop 80: 251-260.

Diemert DJ, Pinto AG, Freire J, Jariwala A, Santiago H, Hamilton RG, Periago MV, Loukas A, Tribolet L, Mulvenna J, Correa-Oliveira R, Hotez P, Bethony JM 2012. Generalized urticaria induced by the $\mathrm{Na}$-ASP-2 hookworm vaccine: implications for the development of vaccines against helminths. J Allergy Clin Immunol 150: 169-176.

dos Santos AP, Bertho AL, Dias DC, Santos JR, Marcovistz R 2005. Lymphocyte subset analyses in healthy adults vaccinated with yellow fever 17DD virus. Mem Inst Oswaldo Cruz 100: 331-337.

dos Santos AP, Bertho AL, Martins RM, Marcovistz R 2007. The sample processing time interval as an influential fator in flow cytometry analysis of lymphocyte subsets. Mem Inst Oswaldo Cruz 102: 117-120.

Fox JP, Cabral AS 1943. The duration of immunity following vaccination with the 17D strain of yellow fever virus. Am J Hyg 37: 93-120.

Fox JP, Cunha JF, Kossobudzki SL 1948. Additional observations on the duration of immunity following vaccination with the 17D strain of yellow fever virus. Am J Hyg 47: 64-70.

Fox JP, Kossobudzki SL, Cunha JF 1943. Field studies on the immune response to 17D yellow fever virus. Am J Hyg 38: 113-138.

Fox JP, Lennette EH, Manso C, Aguiar JRS 1942a. Encephalitis in man following vaccination with $17 \mathrm{D}$ yellow fever virus. $\mathrm{Am} \mathrm{J}$ Hyg 36: 117-142.

Fox JP, Manso C, Penna HA, Pará M 1942b. Observations on the occurrence of icterus in Brazil following vaccination against yellow fever. Am J Hyg 36: 68-116.

Freire MS, Carvalho R, Yamamura AMY, Almeida LFC, Santos HHL, Borges MBJ, Mann GF 2002. Seroconversion following vaccination with the 17DD substrain of yellow fever virus. Virus Rev Res 7: 51-56.

Giuliano AR, Palefsky JM, Goldstone S, Moreira Jr ED, Penny ME, Aranda C, Vardas E, Moi H, Jessen H, Hillman R, Chang Y, Ferris D, Rouleau D, Bryan J, Marshall JB, Vuocolo S, Barra E, Radley D, Haupt RM, Guris D 2011. Efficacy of quadrivalent HPV vaccine against HPV infection and disease in males. $N$ Engl $J$ Med 354: 401-411.

Groot H, Ribeiro RB 1962. Neutralizing and haemagglutination-inhibiting antibodies to yellow fever 17 years after vaccination with 17D vaccine. Bull World Health Organ 27: 699-707.

Hillman RJ, Giuliano AR, Palefsky JM, Goldstone S, Moreira Jr ED, Vardas E, Aranda C, Jessen H, Ferris DG, Coutlee F, Marshall JB, Vuocolo S, Haupt RM, Guris D, Garner EIO 2012. Immunogenicity of the quadrivalent human papillomavirus (type 6/11/16/18) vaccine in males 16 to 26 years old. Clin Vaccine Immunol 19: 261-267.
Kuhn TS 1970. The structure of scientific revolutions, 2nd ed., University of Chicago Press, Chicago, $210 \mathrm{pp}$.

Lindgren-Alves CR, Freire LMS, Oliveira RC, Guerra HL, Da-Silva EE, Siqueira MM, Horta IM, Queiroz CC 2001. Pesquisa de anticorpos contra o sarampo em crianças infectadas pelo HIV após imunização básica. J Pediatr (Rio J) 77: 496-502.

Lopes OS, Guimarães SSDA, Carvalho R 1988. Studies on yellow fever vaccine. III - Dose response in volunteers. J Biol Stand 16: 77-82.

Luiza-Silva M, Campi-Azevedo AC, Batista MA, Martins MA, Avelar RS, Lemos DS, Camacho LAB, Martins RM, Maia MLS, Farias RHG, Freire MS, Galler R, Homma A, Ribeiro JGL, Lemos JAC, Martins MA, Eloi-Santos SM, Teixeira-Carvalho A, Martins-Filho OA 2011a. Cytokine signatures of innate and adaptive immunity in 17DD yellow fever vaccinated children and its association with the level of neutralizing antibody. J Infect Dis 204: 873-883.

Luiza-Silva M, Martins MA, Espírito-Santo LR, Campi-Azevedo AC, Silveira-Lemos D, Ribeiro JGL, Homma A, Kroon EG, Teixeira-Carvalho A, Eloi-Santos SM, Martins-Filho OA 2011b. Characterization of main cytokine sources from the innate and adaptive imune responses following primary 17DD yellow fever vaccination in adults. Vaccine 29: 583-592.

Luna EJ, Moraes JC, Silveira L, Salina HSN 2009. Efficacy and safety of the Brazilian vaccine against hepatitis B in newborns. Rev Saude Publica 43: 1-6.

Machado-Pinto J, Pinto J, da Costa CA, Genaro O, Marques MJ, Modabber F, Mayrink W 2002. Immunochemotherapy for cutaneous leishmaniasis: a controlled trial using killed Leishmania amazonensis vaccine plus antimonial. Int J Dermatol 41: 73-78.

Martins MA, Silva ML, Elói-Santos SM, Ribeiro JGL, PeruhypeMagalhães V, Marciano APV, Homma A, Kroon EG, TeixeiraCarvalho A, Martins-Filho OA 2008a. Innate immunity phenotypic features point toward simultaneous raise of activation and modulation events following 17DD live attenuated yellow fever first-time vaccination. Vaccine 26: 1173-1184.

Martins MA, Silva ML, Marciano APV, Peruhype-Magalhães V, Eloi-Santos SM, Ribeiro JGL, Correa-Oliveira R, Homma A, Kroon EG, Teixeira-Carvalho A, Martins-Filho OA 2007. Activation/modulation of adaptive immunity emerges simultaneously after 17DD yellow fever first-time vaccination: is this the key to prevent severe adverse reactions following immunization? Clin Exp Immunol 148: 90-100.

Martins RM 2014. Análises de estudos clínicos com vacinas realizados no âmbito do Instituto Oswaldo Cruz e Fiocruz - memória, avaliação e lições, PhD Thesis, Instituto Oswaldo Cruz, Rio de Janeiro, 310 pp.

Martins RM, Barbosa GG, Maia MLS, Engstrom E, Camacho LAB, Périssé AR, Silveira IAFB, Leal ML, Marcovistz R, Homma A, Jessouroun E 2010. Phase I study of a meningococcal C strain 2135 conjugate vaccine. Proceedings of the 17th International Pathogenic Neisseria Conference, 11-16 September 2010, Banff, Canada, IPNC, Banff, p. 169.

Martins RM, Bensabath G, Arraes LC, Oliveira MLA, Miguel JC, Barbosa GG, Camacho LAB 2004. Multicenter study on the immunogenicity and safety of two recombinant vaccines against hepatitis B. Mem Inst Oswaldo Cruz 99: 865-871.

Martins RM, Camacho LAB, Marcovistz R, de Noronha TG, Maia MLS, dos Santos EM, Barbosa GG, da Silva AMV, de Souza PCNF, Lemos MCF, Homma A 2008b. Immunogenicity, reactogenicity and consistency of production of a Brazilian combined vaccine against diphtheria, tetanus, pertussis and Haemophilus influenzae Type b. Mem Inst Oswaldo Cruz 103: 711-718. 
Martins RM, Camacho LAB, Périssé AR, Santos TM, Silveira IAFB, Maia MLS, Marcovistz R, Maia MLS, Homma A, Jessouroun E 2009a. Phase I safety and immunogenicity study of a serogroup C conjugate vaccine - Lessons learned. In Neisseria vaccines 2009, Finlay Ediciones, Havana, p. 41.

Martins RM, Homma A, Migowski E 2013a. Imunizações. In JR Coura, Dinâmica das doenças infecciosas e parasitárias, Guanabara Koogan, Rio de Janeiro, p. 431-443.

Martins RM, Maia MLS, Farias RHG, Camacho LAB, Freire MS, Galler R, Yamamura AMY, Almeida LFC, Lima SMB, Nogueira RMR, Sá GRS, Hokama DA, Carvalho R, Freire RAV, Pereira Filho E, Leal MLF, Homma A 2013b. 17DD yellow fever vaccine. A Double blind, randomized clinical trial of immunogenicity and safety on a dose-response study. Hum Vaccin Immunother 9: 1-10.

Martins RM, Périssé AR, Camacho LAB, Santos TM, Silveira IAFB, Leal ML, Maia MLS, Homma A, Jessouroun E 2009b. Phase I safety and immunogenicity study of a Brazilian bivalent serogroup B vaccine. In Neisseria vaccines 2009, Finlay Ediciones, Havana, p. 40.

Marzochi KBF, Marzochi MCA, Silva AF, Grativol N, Duarte R, Confort EM, Modabber F 1998. Phase 1 study of an inactivated vaccine against American tegumentary leishmaniasis in normal volunteers in Brazil. Mem Inst Oswaldo Cruz 93: 205-212.

Mascarenhas JDP, Leite JPG, Gabbay YB, Freitas RB, Oliveira CS, Monteiro TAF, Linhares AC 2002a. Rotavirus G serotypes and $\mathrm{P}[], \mathrm{G}$ genotypes identified in cases of reinfection among children participating in a trial with rhesus-human reassortant tetravalent vaccine (RRV-TV) in Belém, Brazil. J Trop Pediatr 48: 93-97.

Mascarenhas JDP, Linhares AC, Gabbay YB, Leite JPG 2002b. Detection and characterization of rotavirus $\mathrm{G}$ and $\mathrm{P}$ types from children participating in a rotavirus vaccine trial in Belém, Brazil. Mem Inst Oswaldo Cruz 97: 113-117.

Matos DCS, Silva AMV, Neves PCC, Martins RM, Homma A, Marcovistz R 2009. Pattern of functional antibody activity against Haemophilus influenzae Type b (Hib) in infants immunized with diphtheria-tetanus-pertussis/Hib Brazilian combination vaccine. Braz J Med Biol Res 42: 1242-1247.

Melo AB, Nascimento EJM, Braga-Neto U, Dhalia R, Silva AM, Oelke M, Schneck JP, Sidney J, Sette A, Montenegro SML, Marques ET 2013. T-cell memory responses elicited by yellow fever vaccine are targeted to overlapping epitopes containing multiple HLA-I and II binding motifs. PLoS Negl Trop Dis 7: 1-11.

Melo AB, Silva MPC, Magalhães MCF, Gil LHV, Carvalho EMF, Braga-Neto UM, Bertani GR, Marques Jr ETA, Cordeiro MT 2011. Description of a prospective 17DD yellow fever vaccine cohort in Recife, Brazil. Am J Trop Med Hyg 85: 739-747.

Mendonça SCF, De Luca PM, Mayrink W, Restom TG, ConceiçaoSilva F, Da-Cruz AM, Bertho AL, Costa CA, Genaro O, Toledo VPCP, Coutinho SG 1995. Characterization of human T lymphocyte-mediated immune responses induced by a vaccine against American tegumentary leishmaniasis. Am J Trop Med Hyg 53: 195-201.

Moraes JC, Luna EJA, Grimaldi RA 2010. Immunogenicity of the Brazilian hepatitis B vaccine in adults. Rev Saude Publica 44: 1-5.

Moreira Jr ED, Palefsky JM, Giuliano AR, Goldstone S, Aranda C, Jessen H, Hillman RJ, Ferris D, Coutlee F, Vardas E, Marshall JB, Vuocolo S, Haupt RM, Guris D, Garner EIO 2011. Safety and reactogenicity of a quadrivalent human papillomavirus (types 6 , $11,16,18)$ L1 viral-like-particle vaccine in older adolescentes and young adults. Hum Vaccin 7: 768-775.
Motta MSF, Mussi-Pinhata MM, Jorge SM, Yoshida CFT, Souza CBS 2002. Immunogenicity of hepatitis B vaccine in preterm and full term infants vaccinated within the first week of life. Vaccine 20: 1557-1562.

Motta-Castro ARC, Gomes SA, Yoshida CFT, Miguel JC, Teles SA, Martins RMB 2009. Compliance with and response to hepatitis B vaccination in remaining quilombo communities in central Brazil. Cad Saude Publica 25: 738-742.

Nascimento E, Fernandes DF, Vieira EP, Campos-Neto A, Ashman JA, Alves FP, Coler RN, Bogatzki LY, Kahn SJ, Beckmann AM, Pine SO, Cowgill KD, Reed SG, Piazza FM 2010. A clinical trial to evaluate the safety and immunogenicity of the LEISHF1+MPL-SE vaccine when used in combination with meglumine antimoniate for the treatment of cutaneous leishmaniasis. Vaccine 28: 6581-6587.

Neves PCC, Matos DCS, Marcovistz R, Galler R 2009. TLR expression and NK activation after human yellow fever vaccination. Vaccine 27: 5543-5549.

Oliva OP, Chaves JRS, Loureiro MLP, Pereira LA, Homma A 1986. Vacina CAM-70 contra o sarampo produzida no Brasil. Avaliações de campo em crianças com 6-12 meses de idade. Boletim Epidemiológico 18: 121-126.

Oliveira ES, Marinho JM, Barbosa T 2013. Interferon-gamma production by mononuclear cells in Bacille Calmette-Guérin-revaccinated healthy volunteers predicted long-term antimycobacterial responses in a randomized controlled trial. Vaccine 31: 3778-3782.

Palefsky JM, Giuliano AR, Goldstone S, Moreira Jr ED, Aranda C, Jessen H, Hillman R, Ferris D, Coutlee F, Stoler MH, Marshall JB, Radley D, Vuocolo S, Haupt RM, Guris D, Garner EIO 2011. HPV vaccine against anal HPV infection and anal intraepithelial neoplasia. $N$ Engl J Med 365: 1576-1585.

Patriarca PA, Palmeira G, Lima Filho J, Cordeiro MT, Laender F, Oliveira MJC, Dantes MCS, Risi Jr JB 1988. Randomised trial of alternative formulations of oral poliovaccine in Brazil. Lancet 27: 429-432.

Plotkin AS 2011. History of vaccine development, Springer, New York, $349 \mathrm{pp}$.

Potsch DV, Camacho LAB, Tuboi S, Villar LM, Miguel JC, Ginuino C, Silva EF, Mendonça RMM, Moreira RB, Barroso PF 2012. Vaccination against hepatitis $\mathrm{B}$ with 4-double doses increases response rates and antibodies titers in HIV-infected adults. Vaccine 30: 5973-5977.

Potsch DV, Oliveira MLA, Ginuino C, Miguel JC, Oliveira SAN, Silva EF, Moreira RB, Cruz GVM, Oliveira ALVSM, Camacho LAB, Barroso PF 2010. High rates of serological response to a modified hepatitis B vaccination schedule in HIV-infected subjects. Vaccine 28: 1447-1450.

Puffer RR, Serrano CV 1973. Características de la mortalidad en la niñez: informe de la Investigación Interamericana de la Niñez, Organización Panamericana de la Salud, Washington DC, 490 pp.

Santini-Oliveira M, Camacho LAB, Souza TML, Luz PM, Vasconcellos MTL, Giacoia-Gripp CBW, Morgado MG, Nunes EP, Lemos AS, Ferreira ACG, Moreira RI, Veloso VG, Siqueira MM, Grinsztejn B 2012. H1N1 pdm09 adjuvanted vaccination in HIV-infected adults: a randomized trial of two single versus two double doses. PLOS ONE 7: 1-11.

Santos AP, Matos DCS, Bertho AL, Mendonça SCF, Marcovistz R 2008. Detection of TH1/ TH2 cytokine signatures in yellow fever 17DD first-time vaccinees through ELISpot assay. Cytokine 42: 152-155. 
Santos DM, Carneiro MW, de Moura TR, Soto M, Luz NF, Prates DB, Irache JM, Brodskyn C, Barral A, Barral-Netto M, Espuelas S, Borges VM, de Oliveira CI 2013. PLGA nanoparticles loaded with KMP-11 stimulate innate immunity and induce the killing of Leishmania. Nanomedicine 9: 985-995.

Schatzmayr HG, Homma A 1969. Avaliação sorológica da vacina oral, tipo Sabin, contra a poliomielite, em região semi-rural. I. Formação de anticorpos em vacinados. Rev Soc Bras Med Trop 3: 317-322.

Schatzmayr HG, Maurice Y, Fujita M, Fillipis AMB 1986. Serological evaluation of poliomyelitis oral and inactivated vaccines in an urban low-income population at Rio de Janeiro, Brazil. Vaccine 4: 111-113.

Schatzmayr HG, Nogueira RMR, Bermudez JAZ, Pinhão AT, Queiroz B, Venâncio LR, Assis CER, Shiraiwa T 1982. Serological response to measles vaccine (Schwarz strain) in a low-income population at Rio de Janeiro. Rev Microbiol 13: 242-249.

Silva JRN, Camacho LAB, Siqueira MM, Freire M, Castro YP, Maia MLS, Yamamura AMY, Martins RM, Leal MLF, Grupo Colaborativo para o Estudo das Vacinas de Febre Amarela 2011. Mutual interference on the immune response to yellow fever vaccine and a combined vaccine against measles, mumps and rubella. Vaccine 29: 6327-6334

Smith HH, Penna HA, Paoliello A 1938. Yellow fever vaccination with cultured virus (17D) without immune serum. Am J Trop Med Hyg 18: 437-468.

Soper FL, Smith HH 1938. Yellow fever vaccination with cultivated virus and immune and hyperimmune serum. Am J Trop Med Hyg 18: 111-134.

Stefano I, Sato HK, Pannuti CS, Omoto TM, Mann G, Freire MS, Yamamura AMY, Vasconcelos PFC, Oselka GW, Weckx LW, Salgado MF, Noale LFO, Souza VAUF 1999. Recent immunization against measles does not interfere with the sero-response to yellow fever vaccine. Vaccine 17: 1042-1046.

Urdaneta M, Prata A, Struchiner CJ, Tosta CE, Tauil P, Boulos M 1996. Safety evaluation of SPf66 malaria vaccine in Brazil. Rev Soc Bras Med Trop 29: 497-501.

Urdaneta M, Prata A, Struchiner CJ, Tosta CE, Tauil P, Boulos M 1998. Evaluation of SPf66 malaria vaccine efficacy in Brazil. Am J Trop Med Hyg 58: 378-385. 